Volume 57

Issue 1 Visualizing Law in the Digital Age

Article 2

January 2013

\title{
The First Amendment and the Second Commandment
}

Amy Adler

NYU School of Law

Follow this and additional works at: https://digitalcommons.nyls.edu/nyls_law_review

Part of the First Amendment Commons, and the Supreme Court of the United States Commons

\section{Recommended Citation}

Amy Adler, The First Amendment and the Second Commandment, 57 N.Y.L. SCH. L. REV. (2012-2013).

This Article is brought to you for free and open access by DigitalCommons@NYLS. It has been accepted for inclusion in NYLS Law Review by an authorized editor of DigitalCommons@NYLS. 
AMY ADLER

\section{The First Amendment and the Second Commandment}

57 N.Y.L. Sсн. L. Rev. 41 (2012-2013)

ABOUT THE AUTHOR: Emily Kempin Professor of Law, NYU School of Law.

I dedicate this article to the memory of Ed Baker, a great friend and a great First Amendment scholar. Many thanks to Richard Sherwin, Cynthia Adler, and Ulad Belavusau for comments on previous drafts and to Ed Baker for earlier conversations. Many thanks as well to Felicity Kohn and Haley Anderson for superb research assistance. Thanks to the Filomen D'Agostino and Max E. Greenberg Research Fund for generous support. I am grateful to Richard Sherwin and Peter Goodrich for organizing such a remarkably rich symposium. This article draws on and extends material first developed in two of my previous pieces, The Art of Censorship (2000) and Inverting the First Amendment (2001). An earlier version of this article appeared in Law, Culture, and Visual Studies (Anne Wagner \& Richard Sherwin eds., Springer 2013). 
THE FIRST AMENDMENT AND THE SECOND COMMANDMENT

Thou shalt not make unto thee any graven image, or any likeness of any thing that is in heaven above, or that is in the earth beneath, or that is in the water under the earth.

- Exodus $^{1}$

The ancient superstitions about images - that they take on lives of their own, that they make people do irrational things, that they are potentially destructive forces that seduce and lead us astray-are not quantifiably less powerful in our time.

- W.J.T. Mitchell ${ }^{2}$

\section{INTRODUCTION}

We live in an image culture, a world in which images are so ubiquitous as to be unremarkable. It is said that the image has surpassed the word as the dominant mode of communication. It seems preposterous to suggest that in this modern, digital, visual culture, we might still feel the ancient, bewitching pull of images, the instinct that images possess an uncanny power or danger. Surely, this view of images is archaic; it resembles the view that motivated both idolaters and iconoclasts in earlier, supposedly more primitive, cultures. Yet I believe this ancient view of images is alive and well—although we do not acknowledge it—in the modern and supposedly rationalistic world of contemporary First Amendment law. In my view, First Amendment law consistently and unthinkingly offers more protection to text than to image, and it does so for reasons that bear a remarkable similarity to the reasons that motivated iconoclasts and iconophiles throughout the history of religious and secular struggles over images.

I have two major goals in this article. The first is to establish that the First Amendment offers greater protection for verbal as opposed to visual forms of representation. The preference for text over image surfaces in a variety of places in First Amendment thinking. It is, however, a peculiar preference, often assumed but almost never acknowledged. Yet the different treatment of text and image within the First Amendment has significant real world implications. It is evident, for example, in the pattern of contemporary obscenity prosecutions, which have focused exclusively on pictorial rather than textual material. The preference for text also arises in child pornography law, which focuses exclusively on pictures. It also turns up as an assumption in a variety of scholarly thinking. For example, Catharine MacKinnon's antipornography writing argues that pictorial pornography, especially photography, is far more harmful to women than is textual pornography. The uncertain status of visual images, in my view, also influences the Court's jurisprudence about the U.S. flag.

1. Exodus 20:4 (King James).

2. W.J.T. Mitchell, What Do Pictures Want?: The Lives and Loves of Images 19 (2005) (internal quotation marks omitted). 
My second goal in this essay is to trace the ways in which the First Amendment treatment of images echoes the approach to visual imagery that animated the biblical prohibition on graven images and the historical, religious impulse to destroy images. The view of images that motivated iconoclasts-the perception of images as invested with magic powers or indistinguishable from what they represent-persists unrecognized in contemporary First Amendment law and theory.

Part II offers a very brief introduction to the complex underpinnings of the biblical prohibition on graven images and historical outbreaks of iconoclasm by focusing on one theme that recurs in the literature-the fear that images might somehow merge with their prototypes. Part III then turns to the argument that there is a First Amendment hierarchy that offers greater protection to text over image. Here I explore four areas of First Amendment law and theory in order to tease out the thematic concerns about images that underlie this unrecognized hierarchy. Ultimately, I argue that the First Amendment hierarchy offering greater protection to verbal over visual representation rests on assumptions about visuality that have biblical rather than constitutional roots.

\section{ICONOCLASM AND THE FEAR OF IMAGES}

In Exodus, chapter twenty, verse four, the Second Commandment of the Hebrew Bible commands: "Thou shalt not make unto thee any graven image, or any likeness of any thing that is in heaven above, or that is in the earth beneath, or that is in the water under the earth." ${ }^{3}$ The biblical prohibition on graven images is an extraordinarily complex subject, and I could not begin to do it justice in the confines of this condensed account. Instead, I focus on one central theme in the religious literature that I believe is particularly relevant to First Amendment law and theory: the fear that visual images were so powerful that they would provoke viewers to confuse the image with its prototype, leading to a dangerous merger of signifier and signified. ${ }^{4}$ This theme informed not only the Second Commandment; it also resurfaced as a prominent justification in numerous outbreaks of iconoclasm.

David Freedberg argues that throughout the history of iconoclastic controversies, across cultures and religions, run certain recurrent assumptions about the nature of images. Whether it be the great iconoclastic movements of Byzantium in the eighth or ninth century, of Reformation Europe, of the French Revolution or the Russian Revolution, or even of modern day, seemingly isolated attacks on art, one of the most prominent fears expressed by iconoclasts has been that the image will somehow merge (or be seen by others to merge) with what it represents. ${ }^{5}$ As the image tempts us to

3. Exodus, supra note 1.

4. See David Freedberg, The Power of Images: Studies in the History and Theory of Response 378-428 (1989); Moshe Halbertal \& Avishai Margalit, Idolatry 37-66 (Naomi Goldblum trans., 1992).

5. See Halbertal \& Margalit, supra note 4; see also Hans Belting, Likeness and Presence: A History of the Image before the Era of Art 145 (Edmund Jephcott trans., Univ. of Chicago Press 1994) (1990) (arguing that the "difference between representation and the person represented had ... become unclear" in debates over iconoclasm). 


\section{THE FIRST AMENDMENT AND THE SECOND COMMANDMENT}

fuse it with what it represents, this becomes the basis of idolatry. One danger of making an image of God is that we might become so entranced with the image that we end up worshipping the thing itself, forgetting that it is only a representation. The image is so beguiling that we lose all sense. The next step, of course, is iconoclasm. Thus, it is a premise of this article that idolatry and iconoclasm are two sides of the same coin: both views depend on the attribution of extraordinary power to images. ${ }^{6}$

The Second Commandment's prohibition on graven images was handed down from Moses to the people on tablets in the midst of the "Golden Calf" episode of the Bible. ${ }^{7}$ Moses went to receive the Word of God and, in his absence, the Israelites became distracted. They built the Golden Calf, a glittering golden image, and began dancing around it as they lapsed into decadent sensuality and distraction. When Moses returned with the inscribed Word of God, he broke the tablets in anger at what he beheld. This idolatry was no small matter: Moses killed 3000 men; he burnt the Golden Calf, strewing its dust into the water, and made the people drink it. Only then did Moses give God's commandments once again to the Israelites. This passage, which marks the elevation of the Word over the image in the Bible, vividly illustrates the hazardous sensuality of visual representation. The voluptuousness and seductiveness of the image, its power beyond words, and its appeal to the senses and to passion rather than reason paved the way for both worship and condemnation.

Why do images but not words invite such a response? Why does the biblical prohibition apply only to pictorial representation? Indeed, verbal representations of God are not only permitted but encouraged. As Moshe Halbertal and Avishai Margalit argue in their definitive account of the biblical prohibition on idolatry, the potential confusion between representation and prototype is unique to pictorial representation. ${ }^{8}$ They write: "This blurring of the distinction between the symbol and the thing symbolized, which is so common in idolatry, does not occur in language . . . "9 The tendency to equate images with what they represent, to invest them with magical powers, recurs across a number of contexts: not only in the longstanding worship of images as religious icons or in the belief that certain pictures have talismanic properties, but also in the widespread fear among native peoples that a picture captures your soul, ${ }^{10}$ the use of voodoo dolls, or the burning of enemies in effigy. All of these various uses of images depend on a fusion between representation and its subject or its effects.

6. The idolater perceives the image as having power over himself. The iconoclast fears that others perceive the picture as having power over them. The image's power is to be celebrated in the former case and destroyed in the latter. Cf. Freedberg, supra note 4, at 405 ("[T] he love and fear of images . . are indeed two sides of one coin.").

7. Exodus 32:1-35 (King James).

8. See Halbertal \& Margalit, supra note 4, at 52 (although acknowledging a qualification to this rule, citing the potential fetishization of the Torah or occasionally of names).

9. $I d$.

10. See James George Frazer, The Golden Bough: A Study in Magic and Religion 164-65 (Robert Fraser ed., Oxford Univ. Press abr. ed. 1994) (1922). 
This interest in the power of images that informs the religious literature also characterizes a great deal of contemporary, secular criticism in the field of visual studies. In recent years, in fact, some have said that the field of visual studies has taken an "iconic turn," marking a newfound fascination with the autonomous power of images, their ability to determine their own reception. ${ }^{11}$ The use of the term "iconic" in this literature deliberately conjures up the concept of divine presence immanent in religious icons. Of course, many critics still resist this turn, and some resist the very assumption that there is a marked distinction between text and image, as did Nelson Goodman and, to a lesser extent, E.H. Gombrich in an earlier wave of criticism. ${ }^{12}$ Nonetheless, for purposes of this essay, I will assume some difference between pictorial and linguistic representation, at least at the very important level with which I am concerned: the level of cultural and, as I will now explore, legal reception.

What are the First Amendment implications of this tendency to attribute life to images, to imagine them as fusing signifier and signified? I believe it leads to two seemingly paradoxical results: on the one hand, it may lead us to view images as trivial or unimportant in the First Amendment hierarchy, so trivial that they might not even qualify as "speech" for constitutional purposes. As signifier merges with signified and the image becomes a thing, we may forget that we are in the presence of representation, of speech, at all. In this view, the First Amendment would not even apply to images.

On the other hand, this same merger between signifier and signified can lead to the view that images are anything but trivial. Instead, they possess a magical, uncontrollable autonomy, a threat that requires us to restrain them. In this view, images would count as "speech" for First Amendment purposes, but they are such a peculiarly dangerous type of speech that typically protective First Amendment rules should not apply to them. ${ }^{13}$ Below, I will explore how both views of images play themselves out in free speech law and theory.

\section{THE PREFERENCE FOR TEXT OVER IMAGE IN FIRST AMENDMENT LAW AND THEORY}

Drawing on this analysis, in this part, I explore four areas of First Amendment law and theory in order to trace the ways in which I believe age-old assumptions about visuality assert themselves in the modern First Amendment context. ${ }^{14}$

11. See Keith Moxey, Visual Studies and the Iconic Turn, 7 J. Visual Culture 131 (2008); Gottrried Boenm, Die Wiederkebr der Bilder, in Was Ist Ein Bild 11-38 (1994). See generally Belting, supra note 5.

12. See, e.g., Nelson Goodman, Languages of Art (2d ed. 1976); Ernst Gombrich, Art \& Illusion (6th ed. 2002).

13. Perhaps this double vision of images as both trivial and dangerous bears something in common with what W.J.T. Mitchell suggested when he wrote: "We need to account not just for the power of images but their powerlessness, their impotence, their abjection.” Mitchell, supra note 2, at 10.

14. These four examples do not exhaust the field. Another significant impact of the text image hierarchy on First Amendment law may be observed in the longstanding uncertainty about the status of visual art in free speech law. I discuss this problem in an earlier piece, Amy Adler, The Art of Censorship, 103 W. VA. L. Rev. 205, 210 (2000). I draw on some of that discussion here. 
THE FIRST AMENDMENT AND THE SECOND COMMANDMENT

\section{A. Obscenity Law}

"[W]hatever images are, ideas are something else."

- W.J.T. Mitchel1 ${ }^{15}$

In the 1973 case of Kaplan v. California, the Supreme Court offered in dicta its only overt acknowledgement of the preferred status of text over image in First Amendment law. ${ }^{16}$ Kaplan involved the obscenity prosecution of an adult book store owner for selling an "unillustrated" book to an undercover officer. ${ }^{17}$ The Court described the book as "made up entirely of repetitive descriptions of physical, sexual conduct, 'clinically' explicit and offensive to the point of being nauseous." ${ }^{18}$

The problem the Supreme Court confronted in Kaplan was that the book contained no pictures. Could mere words be considered obscene? The Court's answer was a cautious "yes." Although it held that words alone could indeed be obscene in some cases, the Court also warned that the prosecution of text should give us greater pause than the prosecution of images..$^{19}$ Yet the Court's opinion was maddening in its failure to explain or justify its distinction between words and images. In a remarkably unilluminating passage, Chief Justice Burger offered the following account of the preferred status of text over image in obscenity law:

Because of a profound commitment to protecting communication of ideas, any restraint on expression by way of the printed word or in speech stimulates a traditional and emotional response, unlike the response to obscene pictures of flagrant human conduct. A book seems to have a different and preferred place in our hierarchy of values, and so it should be. ${ }^{20}$

Why should it be so? Why do words have a different and preferred place in our hierarchy of values? Chief Justice Burger offers "tradition" and emotion in place of analysis. "So it should be" is his ultimate argument. In my view, certain deep but unspoken assumptions about both the meaning of the First Amendment and about the distinction between text and image underlie Burger's assertion.

First, Chief Justice Burger's comment assumes a basic, commonplace First Amendment hierarchy in which protected speech is contrasted to unprotected conduct. Second, he assumes that the danger of prohibiting speech is that to do so will interfere with "the communication of ideas." ${ }^{11}$ This is an unsurprising assumption, given that the most predominant rationale for protecting speech under the First Amendment is the fabled metaphor of "the marketplace of ideas."

\footnotetext{
15. W.J.T. Mitchell, Iconology: Image, Text, Ideology 6 (1986).

16. 413 U.S. 115 (1973).

17. Id. at $116-17$.

18. Id.

19. Id. at 119 .

20. Id.

21. $I d$.
} 
What is perhaps more surprising is that Burger's statement maps the text/image dichotomy onto the speech/conduct one. ${ }^{22}$ His account assumes an association between text and ideas and thus assumes, by virtue of the marketplace of ideas metaphor, an association between text and speech. In contrast, he associates images with conduct and the body- both terms that have at times served as shorthand for "not speech." ${ }^{23}$ Distinguishing the lofty world of words from "obscene pictures of flagrant human conduct," ${ }^{24}$ Burger seems to envision the category of pictures itself as flagrant and debased. They are so closely associated with the conduct they depict that they somehow merge with it, becoming conduct-like rather than speech-like. Indeed, this is a common reaction to images, which are often perceived as if they were unmediated..$^{25}$ Burger's hierarchical associations recall what W.J.T Mitchell terms "the familiar claim that pictures cannot make statements or communicate precise ideas." 26 Embedded in Chief Justice Burger's assertion, then, are strains of the longstanding anxieties about images we saw earlier: images are lowly, sensual, and divorced from the realm of reason and ideas; they are so connected with our body and our senses that pictures become fused with what they represent. They cease to be representations.

Chief Justice Burger wrote of the preferred status of text, "So it should be." And so it was: since Kaplan, the preference for text over image in obscenity law has become the rule in "contemporary obscenity prosecutions, which have focused almost exclusively on pictorial rather than textual material." ${ }^{27}$ The influential Attorney General's Commission on Pornography noted and encouraged this prosecutorial trend in 1986. Citing the Kaplan Court, the Attorney General's report described the "special concern for the written word," as compared to images, in free speech law. ${ }^{28}$ The report observed that there is "for all practical purposes, no prosecution of [purely textual] materials now. ${ }^{29}$ With two recent notable exceptions (in cases that compensate, as I have argued, for the limits of child pornography law), this trend in obscenity law of prosecuting only visual rather than verbal material has continued unabated. ${ }^{30}$

22. For a discussion of the vexed speech/conduct distinction in First Amendment law, see Amy Adler, Inverting the First Amendment, 149 U. PA. L. Rev. 921 (2001).

23. See id. For a discussion of the relationship between the body and speech, see generally Amy Adler, Performance Anxiety: Medusa, Sex, and the First Amendment, 21 Yale J.L. \& Human. 227 (2009).

24. Kaplan, 413 U.S. at 119.

25. Goodman, of course, disagrees with this perception. See Goodman, supra note 12.

26. Mitchell, supra note 15 , at 66 .

27. Adler, supra note 14.

28. Att'y Gen. Comm'n on Pornography, Final Report 384 (1986) [hereinafter Att'y Gen. Report].

29. Id.

30. See Amy Adler, All Porn All the Time, 31 N.Y.U. Rev. L. \& Soc. Change 695 (2007) (describing recent trend of using obscenity law to compensate for limits of child pornography law); see also United States v. Whorley, 550 F.3d 326, 343, 350 (4th Cir. 2008) (Gregory, J., concurring in part and dissenting in part) (arguing that the text-only emails should be protected as "pure speech" and insisting on the special importance of words as opposed to images in the First Amendment because of the special "ability to 
THE FIRST AMENDMENT AND THE SECOND COMMANDMENT

\section{B. Catharine MacKinnon and the Feminist Critique of Pornography}

"Photography has something to do with resurrection." - Roland Barthes ${ }^{31}$

"The image is a kind of threat."

$$
\text { - David Morgan }{ }^{32}
$$

"The image is the sign that pretends not to be a sign, masquerading as (or for the believer, actually achieving) natural immediacy and presence."

- W.J.T. Mitchell ${ }^{33}$

Antipornography feminist Catharine MacKinnon is a scathing critic of almost every facet of the Supreme Court's obscenity jurisprudence. Yet, surprisingly, MacKinnon's approach to sexual materials bears one thing in common with the Supreme Court's: she, too, assumes a hierarchy of text over image. The Court and MacKinnon disfavor images for different reasons, however. Whereas the Court distinguishes text from image in obscenity jurisprudence on the assumption that images are lowly and unimportant, MacKinnon singles out images because she views them as far more dangerous than words.

MacKinnon's basic argument against pornography is as follows: we should censor it not because it is immoral or worthless-reasoning that comes from obscenity law-but because it constructs a world of violence, subjugation, and inequality for women. ${ }^{34}$ Pornographic images are doubly harmful from MacKinnon's perspective. First, she argues, they are inseparable from the violent action that produced them: the pictures are infected with the "female sexual slavery" that she believes is required to produce them. ${ }^{35}$ She emphasizes the violent acts of abuse that go into making pornography: "[W]omen are gang raped so they can be filmed .... [W]omen are hurt and penetrated, tied and gagged . . . so sex pictures can be made." ${ }^{36}$ Indeed, MacKinnon believes that all pornography-even that made by women who "voluntarily" pose for it -is a product of pervasive violence and inequality. ${ }^{37}$

consider and transmit thoughts and ideas through the medium of the written word" in a case involving textual emails and obscene manga drawings of children).

31. Roland Barthes, Camera Lucida: Reflections on Photography 82 (Richard Howard trans., Hill and Wang 1st Am. ed. 1981) (1980).

32. David Morgan, The Sacred Gaze: Religious Visual Culture in Theory and Practice 145 (2005).

33. Mitchell, supra note 15 , at 43.

34. See Andrea Dworkin \& Catharine A. MacKinnon, Pornography \& Civil Rights: A New Day For Women's Equality 46 (1988).

35. $I d$.

36. Catharine A. MacKinnon, Only Words 15 (1993).

37. Dworkin \& MacKinnon, supra note 34, at 43. She contends that when women consent to pose for pornography, such consent is tainted because "all pornography is made under conditions of inequality based on sex, overwhelmingly by poor, desperate, homeless, pimped women who were sexually abused as children." Id. at 20. 
The second harm MacKinnon attributes to pornography is that it constructs a world in which all women are victimized. Pornographic images, already the product of violence, harm women beyond those in the pictures: they "institutionaliz[e] a subhuman, victimized, and second-class status for women." ${ }^{38}$ She writes: "Social inequality is substantially created and enforced" through pornography. ${ }^{39}$ Arguing that pornography is therefore action, not just speech, she writes that pornography is "a practice of sexual politics, an institution of gender inequality." ${ }^{\prime 0}$ Thus MacKinnon concludes that "pornography is more actlike than thoughtlike" and that it should no longer merit First Amendment protection. ${ }^{41}$

Formally, MacKinnon's work addresses both pictorial and verbal pornography. The model antipornography ordinance she drafted along with feminist theorist Andrea Dworkin specifically defines pornography as "the graphic sexually explicit subordination of women through pictures and/or words." ${ }^{32}$ Yet despite her formal concern for banning words as well as images, it becomes clear upon a closer reading of her work that MacKinnon's main target is pornographic images, not text. As I will suggest below, a special abhorrence for visual pornography emerges in MacKinnon's work.

Why would MacKinnon reserve greater concern for images? I believe that images for her bear a kind of magical power that recalls the power of images in religious, iconoclastic literature. Indeed, the image in MacKinnon's work becomes the site of fusion between the two kinds of harms that she attributes to pornography. As described above, these two harms are temporally distinct. The first type of harm-the violence that it takes to produce pornography-precedes the existence of the picture. The second, social construction harm, occurs after the picture is made; it stems from the effect the image has on its viewers. Yet for MacKinnon these past and future harms are magically compressed in the immortal, timeless space of the photograph. The picture not only is alive with the violent action, the rape, that produced it, but also affects its viewers in a way that causes this violence to reproduce itself. Thus in MacKinnon's work the picture is inextricable from the harm that preceded it and the harm that it conjures up.

Consider the vision of images that appears at the opening of MacKinnon's book, Only Words. The book begins with a harrowing passage that addresses the reader in the second person, commanding her to imagine herself being raped and tortured.

You grow up with your father holding you down and covering your mouth so another man can make a horrible searing pain between your legs. When you are older, your husband ties you to the bed and drips hot wax on your nipples and brings in other men to watch ... . You cannot tell anyone. ${ }^{43}$

38. Catharine A. MacKinnon, Feminism Unmodified: Discourses on Life and Law 200-01 (1987).

39. See MacKinnon, supra note 36, at 13.

40. Catharine A. MacKinnon, Toward a Feminist Theory of the State 197 (1989).

41. Id. at 204 .

42. Dworkin \& MacKinnon, supra note 34, at 36 (emphasis added).

43. MacKinnon, supra note 36, at 3. 
THE FIRST AMENDMENT AND THE SECOND COMMANDMENT

After this account of sexual violation, MacKinnon then turns to the subject of photography: ${ }^{44}$

In this thousand years of silence, the camera is invented and pictures are made of you while these things are being done. You hear the camera clicking or whirring as you are being hurt, keeping time to the rhythm of your pain. You always know that the pictures are out there somewhere, sold or traded or shown around or just kept in a drawer. In them, what was done to you is immortal. He has them; someone, anyone, has seen you there, that way. This is unbearable. What he felt as he watched you as he used you is always being done again and lived again and felt again through the pictures . ... ${ }^{45}$

Note what is going on in this passage. Pictures are so powerful it is as if they are alive with the action they document. Indeed, they are "immortal": through them your violation is "done again and lived again and felt again." Pictures are perpetual, powerful, and curiously animate. Their promiscuity and permanence are part of their powerthey are always "out there somewhere." The camera's click is not just a soundtrack to your pain; the pictures it produces become a site of your eternal re-violation.

Indeed, pictures are so alive with the abuse they document that they have an uncanny, talismanic power to reproduce themselves. In a peculiar passage, MacKinnon writes about the connection between the violence that goes into making pornography and the violence that she believes pornography creates. She writes:

I have come to think that there is a connection between these conditions of production [the force that goes into producing pornography] and the force that is so often needed to make other women perform the sex that consumers come to want as a result of viewing it. In other words, if it took these forms of force to make a woman do what was needed to make the materials, might it not take the same or other forms of force to get other women to do what is in it? ${ }^{46}$

In this passage, MacKinnon invests pictures with talismanic power, as she does at another point when she writes that "[p] ornography brings its conditions of production to the consumer." ${ }^{\prime 47}$ The picture becomes a totem, supernaturally able to reproduce its violent origins when it is seen by future viewers.

MacKinnon's view of images in these passages is remarkably similar to the view that permeates accounts of both iconoclasts and iconophiles. For her, a pornographic picture is like an icon in two ways. First, she collapses signifier and signified: the picture is somehow alive, fused with what it represents. But second, the image, like an icon, is able

44. Many of the questions I discuss here raise issues not only of images in general, but of photography in particular. I have addressed the unusual vulnerability of photography to censorship in prior scholarship. See, e.g., Amy Adler, Photography on Trial, 25 Index on Censorship, no. 3, 1996, at 141. Here I do not focus on photography as a genre, but rather on photography as a subset of images more generally. Like all images, photography often raises assumptions that it is crude, dangerous, powerful, or "true." Although photos often present these assumptions more forcefully than do other types of images, for purposes of this essay, I posit that it is a difference of degree not of kind.

45. MacKinnon, supra note 36, at 3-4.

46. Id. at $20-21$.

47. Id. at 25 . 
to work magic. As Halbertal and Margalit explain, idols typically "become the bearers of the power they represent." ${ }^{48}$ Freedberg describes images as possessing "an effectiveness that proceeds as if the original body were present." ${ }^{\prime 4}$ The thing represented-whether violence or a god or a powerful saint-inheres in the representation; the depiction can miraculously conjure up the power of the thing depicted.

It is no wonder that MacKinnon has insisted when writing about pornography that "representation is reality." ${ }^{50}$ MacKinnon's definition of pornography begins with her assertion that "pornography is . . . the subordination of women." ${ }^{51}$ Pornography does not represent the subordination of women, it does not cause it, it is it. It "is a form of forced sex." ${ }^{2}$ When the Seventh Circuit struck down MacKinnon's antipornography ordinance after it had been enacted into law by the city of Indianapolis, the court seized on and rejected this very point in her reasoning. The court insisted on the distinction between representation and reality, writing: "[T]he image of pain is not necessarily pain." ${ }^{53}$ Yet for MacKinnon, the fusion between visual signifier and signified is precisely her point. She writes, for example: "The most elite denial of the harm [of pornography] is the one that holds that pornography is 'representation ...." 54

By dwelling on images and not on textual pornography as her paradigm of pornographic harm, MacKinnon draws on an age-old model of visual representation. It is the model of both idolaters and iconoclasts, in which pictures bear a special power by being fused with what they depict. ${ }^{55}$

\section{Child Pornography Law}

"[Images] were perilous in themselves, full of the destructive power of their always-suspect origins."

$$
\text { - John Phillips }{ }^{56}
$$

48. Halbertal \& Margalit, supra note 4, at 52.

49. Freedberg, supra note 4 , at 402.

50. MacKinnon, supra note 36, at 29.

51. Dworkin \& MacKinnon, supra note 34, at 36 (emphasis added).

52. MacKinnon, supra note 40, at 197.

53. Am. Booksellers Ass'n v. Hudnut, 771 F.2d 323, 330 (7th Cir. 1985).

54. MacKinnon, supra note 36, at 28.

55. Although I do not discuss it here, another result of this fusion is that MacKinnon, like many others, attributes a special truth value to photography. She writes: "[T] he pictures are not so different from the words and drawings that came before, but your use for the camera gives the pictures a special credibility, a deep verisimilitude, an even stronger claim to truth . ..." Id. at 5. For a classic meditation on the mistaken yet powerful assumption that photographs are "true," see Susan Sontag, On Photography (Picador 2001) (1977).

56. John Phillips, The Reformation of Images: Destruction of Art in England, 1535-1660, at xii (1973). 


\section{THE FIRST AMENDMENT AND THE SECOND COMMANDMENT}

The Supreme Court's child pornography jurisprudence is founded on a radical distinction between text and image. Child pornography law governs only "visual depictions" of child sexual conduct. ${ }^{57}$ Words can never be child pornography, no matter how gruesome or sexually explicit they might be. ${ }^{58}$ In child pornography law, we once again find an area of First Amendment doctrine permeated by unexplored anxieties and assumptions about visuality.

Federal law defines "child pornography" as "any visual depiction, including any photograph, film, video, picture, or computer . . . image or picture . . of sexually explicit conduct" of a child under the age of eighteen. ${ }^{59}$ The law tracks the Supreme Court's approach to child pornography, which it initiated in the 1982 case of New York v. Ferber. ${ }^{60}$ In Ferber, a unanimous Court (extremely rare in First Amendment cases) created a previously unknown exception to the First Amendment, proclaiming that "child pornography" was a new category of speech without constitutional protection. The Ferber Court encountered a novel First Amendment problem: whether nonobscene, ${ }^{61}$ sexual images of children - speech not falling into any previously defined First Amendment exception—could be constitutionally restricted. The Court's answer was yes.

Although Ferber announced five reasons that supported the exclusion of such images from constitutional protection, ${ }^{62}$ the primary thrust of these rationales was

57. 18 U.S.C. § 2256 (2011).

58. Cf. PROTECT Act of 2003, Pub. L. No. 109-21, 117 Stat. 650 (2003) (criminalizing textual accounts of child sexual abuse under the rubric of obscenity law rather than child pornography law); United States v. Whorley, 550 F.3d 326 (4th Cir. 2008) (prosecuting verbal accounts of child sexual conduct as obscenity, not child pornography).

59. 18 U.S.C. \$ 2256(8). Wholly computer generated images are not child pornography since their production does not entail the abuse of a real child. See Ashcroft v. Free Speech Coalition, 535 U.S. 234, 256 (2002) (striking down provisions of Child Pornography Prevention Act that treated "virtual" child pornography as if it were child pornography). This reasoning, which distinguished between "real" images and "virtual" ones, is based in my view on the faulty but common assumption that certain images, especially photographs, are unquestionably "true."

60. 458 U.S. 747 (1982).

61. The materials at issue in Ferber had been found not to be obscene according to a jury. Id. at 752 . Thus the issue for the Court was sharply defined.

62. Id. at 756-64. The five rationales set out in Ferber were as follows: (1) the state has a "compelling" interest in "safeguarding the physical and psychological well-being of a minor." Id. at 756-57 (citations omitted) (internal quotation marks omitted). (2) Child pornography is "intrinsically related to the sexual abuse of children in at least two ways. First, the materials produced are a permanent record of the child's participation and the harm to the child is exacerbated by their circulation. Second, the distribution network for child pornography must be closed" in order to control the production of child pornography. Id. at 759 (footnote omitted). The Court went on to explain that the production of child pornography is a "low-profile clandestine industry" and that "[t]he most expeditious if not the only practical method of law enforcement may be to dry up the market for this material" by punishing its use. $I d$. at 760 . (3) "[T] he advertising and selling of child pornography provide an economic motive for and are thus an integral part of the production" of child pornography. Id. at 761 (footnote omitted). (4) The possibility that there would be any material of value that would be prohibited under the category of child pornography is "exceedingly modest, if not de minimis." Id. at 762. (5) Banning full categories of speech is an accepted approach in First Amendment law and is therefore appropriate in this instance. Id. at 763-64. 
this: child pornography must be prohibited because of the harm done to children in its production. The images lack First Amendment protection because their creation requires a terrible crime: the abuse of an actual child.

Ferber introduced a novel theory into First Amendment law: the theory that a visual representation can be banned because of the underlying illegal act that produced it. This was a remarkable aberration in First Amendment jurisprudence. Indeed, outside of child pornography law, the First Amendment aggressively polices the distinction between a representation and the thing represented. The normal First Amendment rule thus recognizes that a photograph of a criminal act is not the same thing as a crime. If a news photographer captures a picture of a bank robber in the act, for example, we might publish his photograph on the front page of the newspaper, not ban it. As Thomas Emerson wrote: "[T] he basic principles of a system of freedom of expression would require that society deal directly with the [illegal] action and leave the expression alone." ${ }^{63}$

Of course, it is still possible to prosecute the photographer of a crime for any involvement he may have had with the crime itself. The picture does not protect him. ${ }^{64}$ Suppose someone took a picture of a murder. Perhaps, if the photographer had merely happened upon the act and had been unable to intervene, we would laud his journalistic coup. If he had participated in the murder, we would prosecute him for murder. In the most extreme case, if he committed the murder in order to photograph it, we might consider it a particularly perverse murder. But in any of these events, the First Amendment would make it exceedingly difficult to criminalize the photograph of the murder. ${ }^{65}$ And although some might hope that notions of journalistic taste would prevent a newspaper from publishing the picture, First Amendment law would almost certainly protect the newspaper's right to do so.

But consider the law of child pornography: it is the only place in First Amendment law where the Supreme Court has accepted the idea that we can constitutionally

63. Thomas I. Emerson, The System of Freedom of Expression 494 (1970).

64. Cf. MacKinnon, supra note 36, at 4 (suggesting that taking pictures is mistakenly thought to decriminalize underlying crimes of rape by turning it into protected "pornography"). For a statement of the conventional First Amendment rule, see, for example, Cohen v. Cowles Media Co., 501 U.S. 663, 669 (1991).

65. See United States v. Stevens, 130 S. Ct. 1577 (2010) (rejecting Congress's criminalization of images of illegal animal abuse); Bartnicki v. Vopper, 532 U.S. 514, 529-30 (2001) (distinguishing Ferber, 458 U.S. 747) ("[Outside of child pornography law] it would be quite remarkable to hold that speech by a lawabiding possessor of information can be suppressed in order to deter conduct by a non-law-abiding third party.”); Smith v. Daily Mail Publ'g Co., 443 U.S. 97, 102 (1979) (“[S]tate action to punish the publication of truthful information seldom can satisfy constitutional standards."); Landmark Commc'ns, Inc. v. Virginia, 435 U.S. 829, 845 (1978) (upholding the newspaper's right to publish accurate information about confidential judicial proceedings); New York Times Co. v. United States, 403 U.S. 713 (1971) (per curiam) (allowing publication of so-called Pentagon Papers despite the fact that the papers had been stolen from the Pentagon); Food Lion, Inc. v. Capital Cities/ABC, Inc., 194 F.3d 505 (4th Cir. 1999) (holding that torts committed while newsgathering may be actionable, but news that is obtained as a result of those torts is protected expression). 


\section{THE FIRST AMENDMENT AND THE SECOND COMMANDMENT}

criminalize the depiction of a crime in addition to the crime itself. ${ }^{66}$ The Court in Ferber recognized that it was already a crime to abuse a child in order to produce child pornography. It observed that producing such materials is "an activity illegal throughout the Nation." ${ }^{67}$ But the Court consciously chose to permit criminalization of the pictures too. And in doing so, it introduced into its jurisprudence an entirely new rationale for banning speech.

In my view, Ferber made this leap in large part because of the visual nature of the speech at issue. Of course, as I have previously argued, the particularly horrifying subject matter of the material involved-depictions of the molestation of childrenexplains in part the Court's decision to depart from its normal First Amendment rules. But I believe the Court also made this unusual departure in Ferber because the speech involved was visual rather than verbal. When it comes to verbal representations, we insist on the distinction between signifier and signified; when it comes to visual representations, we are tempted to overlook the distinction, to treat the image as if it were the thing itself. Child pornography law thus represents yet another place in First Amendment doctrine where we see the persistence of the age-old tendency to elide visual images with what they represent.

Child pornography law conflates act and image on a rhetorical as well as a legal level. First, we ban the pictures because of the criminality of the underlying act, which is already a novelty in First Amendment law. Then, the rhetoric of the law replicates this compression. The connection between the underlying child abuse and the picture is so strong that courts and legislators often speak of them as if they were one and the same thing, as if the criminality of the act now resides in the picture itself. Courts and legislatures continually repeat the mantra: "[C]hild pornography is child abuse." ${ }^{68}$ The abuse inheres in the image.

Indeed, as in MacKinnon's work, images in child pornography law take on a peculiarly animate quality. Just as MacKinnon sees the image as "immortal," so the Supreme Court views images of child pornography as bearing the power to "haunt the [the child] in future years." ${ }^{69}$ The photograph's timelessness gives it a kind of life; its harm persists "long after the original misdeed took place." ${ }^{\prime 0}$ The photographs possess an uncanny autonomy, as if they were somehow quickened by the abuse they captured. ${ }^{71}$

66. Cf. Stevens, $130 \mathrm{~S}$. Ct. at 1577 (striking down ban on depictions of animal cruelty as unconstitutional and distinguishing between laws that ban committing animal cruelty and unconstitutional laws that ban depicting such acts); see also Brown v. Entm't Merchs. Ass'n, 131 S. Ct. 2729, 2734 (2011) (discussing Stevens and noting the constitutional difference with "forbidding the depiction of animal crueltythough States have long had laws against committing it").

67. Ferber, 458 U.S. at 761.

68. Att'y Gen. Report, supra note 28, at 406.

69. Ferber, 458 U.S. at 759 n.10 (quoting David P. Shouvlin, Preventing the Sexual Exploitation of Children: A Model Act, 17 Wake Forest L. Rev. 535, 545 (1981)).

70. $I d$.

71. The visual nature of the speech at issue explains the Court's novel reasoning on two levels: not only the Court's treatment of the image as if it were the crime itself, explained above, but also the assumption 
The image no longer merely depicts an act, but becomes itself an actor. When the Supreme Court approvingly quoted an article claiming that images of child sexual abuse were more harmful than the actual abuse itself, it seemed to endorse this view of images. The Court wrote: "[p]ornography poses an even greater threat to the child victim than does sexual abuse . . ." 72 In this formulation, the image becomes even more powerful than a physical act of violation. ${ }^{73}$

\section{Flags}

The Supreme Court's flag jurisprudence also bears traces of the religious suspicion about images. Yet oddly, in this realm the Court shows strains of both an iconoclastic and an idolatrous view of the visual. ${ }^{74}$ In West Virginia Board of Education v. Barnette, the Supreme Court struck down a regulation that required children in public schools to salute the flag. ${ }^{75}$ The plaintiffs were parents who brought suit to restrain enforcement of this regulation against their children who were Jehovah's Witnesses. Why did the Jehovah's Witnesses not want to salute the flag? Fittingly for this discussion, their religious beliefs led them to consider the flag a graven image within the prohibition of the Ten Commandments. Saluting the flag was idolatry, as wrong as fetishizing the Golden Calf. Indeed, the Supreme Court in Barnette quoted the Second Commandment's prohibition on graven images to explain the Jehovah's Witnesses' refusal. ${ }^{76}$

The issue in Barnette was the expressive meaning of saluting the flag, which the Court considered a "form of utterance." ${ }^{77}$ Nonetheless, the Court lingered at some length over the meaning of the flag itself as speech. Here the Court gives us another glimpse of its thinking about the strange power of visual speech. In a curious passage, the Court talks about the nature of visual symbols. Justice Jackson writes for the Court: "Symbolism is a primitive but effective way of communicating ideas. The use of an emblem or flag ... is a short cut from mind to mind ...." ${ }^{78}$ Visual images are

that a photograph is indisputably "true." See Sontag, supra note 55 (exploring assumption that images have a deeper connection to truth).

72. Ferber, 458 U.S. at 759 n.10 (quoting David P. Shouvlin, Preventing the Sexual Exploitation of Children: A Model Act, 17 Wake Forest L. Rev. 535, 545 (1981)).

73. This view of images may explain a puzzling recent discrepancy that critics have observed in sentencing law. Sentences for people who download (but do not produce) child pornography are at times so lengthy that they exceed the sentences given to people who commit physical crimes of molestation against children.

74. Of course, as I have claimed, both views share a common vision of images as possessing special power. The account that follows is drawn from Adler, supra note 14, at 213-17.

75. 319 U.S. 624 (1943).

76. See id. at 629 ("Their religious beliefs include a literal version of Exodus, Chapter 20, verses 4 and 5, which says: 'Thou shalt not make unto thee any graven image, or any likeness of anything that is in heaven above, or that is in the earth beneath, or that is in the water under the earth; thou shalt not bow down thyself to them nor serve them."”).

77. Id. at 632 .

78. $I d$. 


\section{THE FIRST AMENDMENT AND THE SECOND COMMANDMENT}

double edged; they are both "primitive but effective." When Justice Jackson says that an image works as a "short cut from mind to mind," he portrays images as forceful, but crude.

There is also a certain treachery to images. The Court's opinion reveals a nagging uncertainty about how to account for the flag's meaning. Consider what Justice Jackson says next: "A person gets from a symbol the meaning he puts into it, and what is one man's comfort and inspiration is another's jest and scorn." ${ }^{79}$ This passage portrays visual symbols as a potentially hazardous form of communication. If the meaning of a visual symbol rests in the mind of the person who sees it, then a speaker who uses a symbol to convey a message runs a risk that the symbol will mean something other than what he intends. Thus alongside the great power of the visual symbol as speech-it is a primitive and effective short cut-runs the danger of betrayal or treachery. The visual symbol is so powerful it may overpower the speaker; he may not be able to control its meaning.

This same ambivalence about the power and the danger of visual images resurfaces in the Court's flag burning cases. In the 1989 case of Texas v. Johnson, the Court struck down the conviction of a man who burned a flag at a political protest at the 1984 Republican convention in Texas. ${ }^{80}$ The defendant had been convicted under a Texas statute that prohibited "desecration" of the American flag. ${ }^{81}$

On First Amendment grounds, Texas v. Johnson should have been an easy case, since the statute at issue fell well within precedents prohibiting content discrimination. But the Court struggled with the case on an emotional if not legal level. Indeed, both the majority and the dissent in Johnson seemed struck by the strange force of the flag as a visual symbol.

The majority in Johnson focused on the special multivalent quality of the flag as a visual image. Just as the Court in Barnette had discussed the way in which the meaning of a visual image would fluctuate dramatically depending on who was viewing it and what his attitude was, the Texas v. Johnson Court dwelled on the flag's unusual capacity to convey multiple meanings. In fact, according to the majority, it was this quality of the flag that explained why the statute at issue was unconstitutional. ${ }^{82}$ The majority reasoned that the problem with the Texas statute was that it restricted use of the flag to send only one message, to express patriotism. ${ }^{83}$ But to limit the flag in this manner was to cut off precisely what is unique and powerful about the symbol: that numerous meanings inhere within it. The Court held that you cannot impoverish the cultural realm by confining the flag to only one

79. Id. at $632-33$.

80. 491 U.S. 397, 399-402 (1989).

81. Id. at 400 (citing Tex. Penal Code Ann. $\$ 42.09$ (West 1989)).

82. See id. at 405 .

83. See id. at 415 . 
meaning when by its nature it is capable of so many different interpretations. ${ }^{84} \mathrm{Visual}$ images by their nature cannot be confined. ${ }^{85}$ In short, you cannot capture the flag.

What is the dissent's response to this? Yes, the majority is right. Yes, the Texas law is an example of content discrimination. Yes, it is even viewpoint discrimination. But this is the flag. And because it is the flag, content discrimination, even viewpoint discrimination, is acceptable. The flag is so important that it should be an exception to all First Amendment principles. ${ }^{86}$

Why? What is it about the flag that should cause us to ignore clear First Amendment precedent? Isn't the flag after all just a piece of cloth? Not according to Justice Rehnquist. In his dissent, he writes about the "mystical reverence" 87 with which people regard the flag, the "uniquely deep awe and respect" 88 that we hold for it. When Justice Rehnquist says the "flag is not simply another 'idea' or 'point of view' competing for recognition in the marketplace of ideas," ${ }^{\prime 9}$ it is as if he is saying that the flag is so powerful, so mystical, and awe-inspiring that it is no longer an idea, no longer speech. In fact, Justice Rehnquist attributes a religious quality to the flag. He mocks the majority opinion for telling us that the First Amendment prohibits the government from insisting on one correct meaning for the flag. When he says "the government has not established" our feeling for the flag, that 200 years of history have done that, he puts the word "established" in quotes, conjuring up the religious establishment cases. ${ }^{90}$

Remember that the Jehovah's Witnesses in Barnette regarded the flag as a graven image. One danger of a graven image, of course, is that it may inspire idolatry. People may worship the image of God rather than God himself. And speaking of idolatry, there is a strange, wonderfully understandable slippage in Justice Rehnquist's opinion. At the close of his rhetorically stirring argument, he writes that the majority's ruling means that men "must fight and perhaps die for the flag, but the government may not prohibit the public burning of the banner under which they fight." 91

Do people really die for the flag? Don't people actually die for what it represents? There is a confusion here between the image and reality. This confusion is of course understandable. To soldiers on a battlefield in the heat of terror and violence, the sight of the flag may become so fused with what it represents - their side; living vs. dying - that they might feel that they are indeed fighting for the flag. It is a rich and

84. Id. at 417 .

85. Cf. Pleasant Grove City v. Summum, 555 U.S. 460, 475 (2009) (“[T] ext-based monuments are almost certain to evoke different thoughts and sentiments in the minds of different observers, and the effect of monuments that do not contain text is likely to be even more variable.").

86. Johnson, 491 U.S. at 422 (Rehnquist, J., dissenting).

87. Id. at 429.

88. Id. at 434 .

89. Id. at 429 .

90. Id. at 434 .

91. Id. at 435 . 
powerful symbol. But here and at another point where Rehnquist says the flag "embodies" our nation, I think his slippage between the image and what it stands for reveals something deeper about images. They are so strong, such a plain "short cut" to our minds, that they tempt us to conflate representation with reality.

There is an irrationality to Justice Rehnquist's opinion, as if he is caught in the grip of the symbol himself, as if the emotional, mystical, religious power of a visual image has overwhelmed him and made him take an easy case and struggle with it. It is as if the danger of visual images, their primitive force, has manifested itself in this opinion. For a brief moment, Justice Rehnquist has given way to idolatry.

\section{CONCLUSION}

As I have suggested, our free speech preference for text over image rests on a theory of visual representation that is rooted in the Second Commandment of the Bible rather than the supposedly rational confines of First Amendment jurisprudence. What are the implications of this argument? I am making a claim not only about visuality and the persistence of historical, magical attitudes toward the visual; I am also making an implicit claim about the nature of First Amendment law more generally.

This article continues to build what I call a "cultural theory of the First Amendment." ${ }^{\prime 2}$ Normally we presume that First Amendment law is rational and objective, based on a continually evolving, often contested, set of legal principles. When we question these assumptions, we often limit our discussion to whether "politics" is a force that could undermine claims to law's neutrality. In this piece, however, I suggest a very different vision of the First Amendment: as a body of law that is surprisingly irrational and contingent. This vision invites us to consider the ways in which legal rules, especially when related to speech, are steeped in cultural anxieties and fantasies. Free speech law governs culture, yet, in surprising ways, culture also governs free speech law.

92. See Amy Adler, Girls! Girls! Girls!: The Supreme Court Confronts the G-String, 80 N.Y.U. L. Rev. 1108, 1154 (2005); Amy Adler, Performance Anxiety: Medusa, Sex, and the First Amendment, 21 Yale J.L. \& Human. 227, 228 (2009). 